\title{
STUDI PERISTIWA DAMPAK REVISI RENEWABLE ENERGY DIRECTIVE TERHADAP PERUSAHAAN PERKEBUNAN KELAPA SAWIT DI INDONESIA
}

\author{
Ilham Gresnaidi ${ }^{1}$, Rahmat Agus Santoso ${ }^{2}$, Anita Handayani ${ }^{3}$ \\ 1,2Program Studi Manajemen, Fakultas Ekonomi dan Bisnis, \\ Universitas Muhammadiyah Gresik, Gresik, Jawa Timur, Indonesia \\ $\underline{\text { ilham.gresnaidi@gmail.com }}^{1}, \underline{\text { ra_santoso@umg.ac.id }}{ }^{2} \underline{\text { anita.handayani@umg.ac.id }}^{3}$
}

\begin{abstract}
Background - Indonesia is one of the most significant crude palm oil exported. But, the amendment of Renewable Energy Directive also brings impact to these industries. The content of the amendment that proposed is to minimize the use of crude palm oil in Europe, while Europe is also the biggest imported of Indonesia crude palm oil.

Objective - This study aims to determine wether there is the difference on abnormal return before and after the proposed Delegated Act, European Parliament vote of proposed Delegated Act and European Council, Commission and Parliament meetings for proposed Delegated Act.

Design/Methodology/Approach - The data used is historical stock price for listed company of Agriculture Sector and Plantation Sub Sector in Indonesia Stock Exchange in 23th November-7th December 2016, 10th-24th January 2018 and 4th-26th June 2018 from investing.com. The assay used in this study is statistic descriptive test, then normality test and then paired sample t-test and/or wilcoxon signed rank test.

Findings - The result of this study indicates there is no difference on abnormal return in all event. That no difference happens because the event contains no information, also the investor believed more in company performance and some information is expired when stock market is open.

Research implications - Research contributes to providing additional information on the impact of the revised Renewable Energy Directive on share prices in energy-producing plantation companies

Research limitations - This study has limitations, namely the trilogy meeting event intersects with the holiday and the Indonesia Stock Exchange holiday, thus creating a conflict of events whether this is the impact of the fitri holiday or because of the trilogy meeting event.
\end{abstract}

Keywords: Abnormal Return, Renewable Energy Directive, Crude Palm Oil, Indonesia

\begin{abstract}
Abstrak
Latar Belakang - Indonesia adalah negara pengekspor minyak kepala sawit terbesar di dunia. Namun, direvisinya Renewable Energy Directive berdampak pada industri ini. Isi proposal revisi Renewable Energy Directive menyebutkan bahwa Eropa tidak akan menggunakan minyak kelapa sawit, sedangkan Eropa adalah salah satu pengimpor minyak kelapa sawit terbesar dari Indonesia.

Tujuan - Penelitian ini bertujuan untuk mengetahui adanya perbedaan abnormal return sebelum dan sesudah peristiwa diajukanya proposal revisi Renewable Energy Directive, pemungutan suara dan pertemuan trilogi.

Desain / metodologi / pendekatan - Jenis data yang digunakan adalah data sekunder berupa data historis harga saham seluruh perusahaan penghasil energi sektor pertanian sub sektor

http://dx.doi.org/10.30587/mahasiswamanajemen.v2i02.2383

Program Studi Manajemen Universitas Muhammadiyah Gresik Jawa Timur Indonesia
\end{abstract}


perkebunan BEI untuk periode 23 November-7 Desember 2016, 10 Januari-24 Januari 2018 dan 4 Juni-26 Juni 2018 yang diunduh dari investing.com. Uji yang dilakukan pada penelitian ini adalah uji statistik deskriptif kemudian uji normalitas lalu dilakukan paired sample t-test dan atau wilcoxon signed rank test

Temuan - Hasil dari penelitian ini menunjukan bahwa tidak ada perbedaan abnormal return sebelum dan seudah peristiwa pengajuan proposal revisi Renewable Energy Directive, pemungutan suara dan pertemuan trilogi. Tidak adanya perbedaan tersebut disebabkan karena peristiwa tidak mengandun informasi, investor mempercayakan kinerja perusahaan serta informasi telat masuk.

Implikasi penelitian - Penelitian berkontribusi untuk memberikan informasi tambahan mengenai dampak revisi Renewable Energy Directive terhadap harga saham pada perusahaan perkebunan penghasil energi

Batasan penelitian - Penelitian ini memiliki keterbatasan yaitu peristiwa pertemuan trilogi bersinggungan dengan libur hari raya serta liburnya Bursa Efek Indonesia, sehingga membuat konflik peristiwa apakah ini dampak dari hari raya libur fitri atau karena peristiwa pertemuan trilogi

Kata kunci: Abnormal Return, Renewable Energy Directive, Crude Palm Oil, Indonesia

\section{PENDAHULUAN}

Harga dari sebuah saham merupakan salah satu indikator yang menarik bagi para investor. Harga saham dapat dipengaruhi oleh faktor ekonomi (kuantitatif) ataupun faktor nonekonomi (kualitatif). Harga saham tidak saja dipengaruhi oleh kinerja perusahaan namun juga faktor-faktor diluar hal tersebut, misalkan saja pengaruh dari kondisi stabilitas negara ataupun diterbitkannya aturan-aturan tertentu yang dapat mempengaruhi kinerja perusahaan kedepannya. Pada tahun 2016, Komisi Uni Eropa mengajukan proposal kepada parlemen Eropa yang isinya adalah merekomendasikan dikuranginya penggunaan crude palm oil (minyak sawit) di Eropa sebagai upaya untuk memperbarui peraturan Renewable Energy Directive (RED) jilid pertama.

Renewable Energy Directive adalah aturan-aturan yang berlaku di Eropa untuk mengatur mengenai produksi dan promosi sumber energi terbarukan. Upaya untuk memperbaharui RED dimulai sejak tahun 2015, ketika Otoritas Perdangan Uni Eropa mulai memberlakukan kebijakan-kebijakan khusus untuk perdagangan crude palm oil di Eropa sebagai upaya untuk memerangi perubahan iklim. Pada tahun tersebut, diterbitkan pula sertifikat Roundtable Sustainable Palm Oil (RSPO) yang wajib dicantumkan pada produk sawit dan turunanya yang masuk ke Eropa.

Menurut Badan Pusat Statistik (2017), kelapa sawit adalah komoditas ekspor Indonesia yang memiliki peran penting sebagai penghasil devisa negara selain minyak 
dan gas. Indonesia sendiri juga merupakan produsen dan eksportir kelapa sawit terbesar di dunia. Data dari BPS juga menyebutkan bahwa benua Eropa merupakan negara tujuan ekspor crude palm oil terbesar kedua setelah India. Crude palm oil tersebut awalnya diekspor ke Belanda lalu didistribusikan ke seluruh Eropa. Apabila Eropa memberlakukan aturan terbaru untuk mengurangi penggunaan bahan bakar berbahan dasar minyak sawit, maka Indonesia akan kehilangan pangsa pasar terbesarnya.

Di akhir 2016 Komisi Uni Eropa merevisi peraturan Renewable Energy Directive (RED) terkait pengaturan segala kebijakan mengenai produksi dan promosi sumber energi terbarukan di Uni Eropa. RED memang belum diresmikan secara legistatif, namun wacana revisi RED secara tidak langsung mempengaruhi industri crude palm oil di Indonesia. Pada tanggal 17 Januari 2018, Komisi Uni Eropa melakukan pemungutan suara untuk menentukan diberlakukannya rekomendasi untuk mengurangi penggunaan biofuel yang berbahan dasar crude palm oil hingga 0 persen dimulai pada tahun 2021. Rekomendasi tersebut disetujui sebagai suara mayoritas.

Peristiwa ini mempengaruhi reaksi pasar dan menjadi bad news karena diduga memberikan sinyal negatif bagi investor. Hal ini mengindikasi bahwa 16 perusahaan penghasil bahan baku sektor pertanian subsektor perkebunan yang terdaftar di Bursa Efek Indonesia saat ini sedang tidak kondusif. Tercatat dari Januari hingga April 2018 ekspor year on year minyak kelapa sawit hanya 10,24 juta ton atau turun 4 persen dari periode tahun 2017 (Liputan6, 2018). Reaksi dari pasar ini biasa disebut sebagai signalling theory. Pasar yang bereaksi negatif dapat ditunjukkan melalui data rata-rata total harga saham pada 17 - 18 Januari 2018 sebagai berikut.

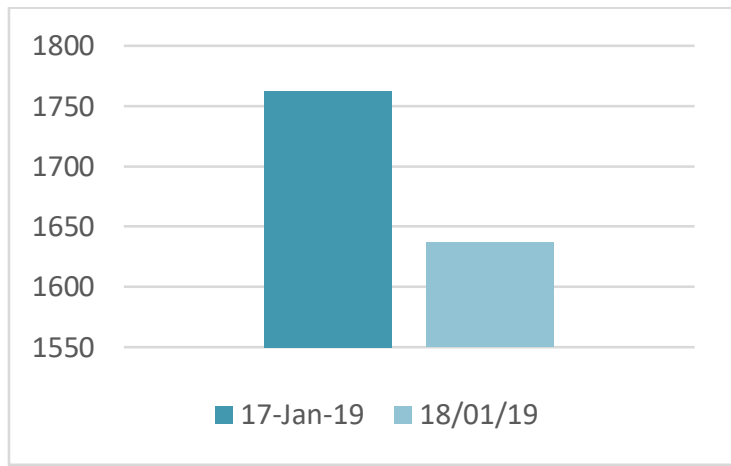

Grafik 1. Tren Rata-Rata Total Harga Saham Pasca Pemungutan Suara Sumber: Diolah Pribadi (2019)

Berdasarkan gambar 1 dapat dilihat bahwa terjadi tren penurunan rata-rata total harga saham pasca pemungutan suara yang dilakukan. Indonesia memberikan 
respon terkait kebijakan tersebut dengan segera membentuk tim lobi untuk merevisi kembali peraturan RED II. Hasil diskusi tersebut menghasilkan kesepakatan bahwa penundaan pemberlakukan kebijakan pengurangan crude palm oil pada biofuel minimal hingga 2030. Hasil kesepakatan tersebut seharusnya menjadi sinyal positif bagi pasar. Reaksi pasar baik itu bad news ataupun good news dapat diketahui melalui uji abnormal return melalui pengujian event study.

Event Study menyelediki respons pasar terhadap kandungan indormasi dari suatu pengumuman atau publikasi peristiwa tertentu (Tandeilin, 2010). Jika abnormal return positif maka peristiwa tersebut adalah good news dan jika negatif maka peristiwa tersebut adalah bad news. Beberapa peneliti terdahulu telah melakukan kajian event study antara lain Arde (2017), Purba dan Handayani (2017), Yulita (2017), dan Sidik (2017). Terjadi perbedaan hasil antara satu peneliti dengan peneliti lain, berikut adalah mapping research gap terkait event study dapat dilihat pada tabel 1.

Tabel 1. Mapping Research Gap

\begin{tabular}{|l|l|}
\hline \multicolumn{1}{|c|}{ Peneliti } & Abnormal Return \\
\hline Hatta Diman Arde (2017) & $\begin{array}{l}\text { Negatif, Signifikan (Pada H+5, H+4, H+2, H+1, H0, } \\
\text { H-3 dan H-5) }\end{array}$ \\
\hline Fransisko Purba (2017) & Negatif, Signifikan (Pada H+1) \\
\hline Ima Krisna Yulita (2017) & Positif, Signifikan (Pada H_2) \\
\hline M. Muhayin A Sidik (2017) & Tidak Signifikan \\
\hline
\end{tabular}

Sumber: Data Diolah Pribadi (2019)

Berdasarkan tabel 1.1 dapat ditarik kesimpulan bahwa peristiwa-peristiwa terorisme dan politik memiliki pengaruh terhadap harga saham ditandai dengan abnormal return yang signifikan, namun peristiwa yang mengangkat isu lingkungan tidak mempengaruhi harga saham. Peneliti bertujuan untuk menganalisis adanya perbedaan abnormal return sebelum ataupun setelah peristiwa pengajuan proposal revisi Renewable Energy Directive.

\section{TINJAUAN PUSTAKA}

\section{Hipotesis Pasar Efisien}

Hartono (2012) mendefinisikan pasar efisien apabila pasar bereaksi dengan cepat dan akurat terhadap suatu informasi yang masuk dan segera membentuk harga keseimbangan yang baru. Tandeilin (2010) menyebutkan bahwa pasar efisien adalah pasar di mana harga sekuritas yang diperdagangkan telah mencerminkan semua 
informasi yang tersedia. Artinya perubahan harga suatu saham di waktu lalu tidak dapat digunakan untuk memperkirakan perubahan harga di masa yang akan datang, penaksiran harga bukan lagi berdasar harga historis saham, melainkan berdasarkan pada informasi yang sedang tersedia dan muncul saat ini di pasar. Tandeilin (2010) menyebutkan ada empat kondisi yang memenuhi tercapainya pasar yang efisien, yaitu:

1. Ada banyak investor yang rasional sehingga berusaha untuk memaksimalkan profit.

2. Semua pelaku pasar dapat memperoleh informasi apda saat yang sama dengan cara yang murah dan mudah.

3. Informasi yang ada bersifat random 'acak'

4. Investor beraksi secara cepat terhadap informai baru sehingga harga sekuritas akan berubah sesuai dengan perubahan nilai sebenarnya akibat informasi baru.

Menurut Bodie dkk. (2014) ada tiga macam bentuk Efficient Market Hypothesis:

1. Pasar efisien bentuk lemah. Pasar dapat diklasifikasikan sebagai pasar bentuk lemah apabila harga saham mencerminkan informasi berdasarkan volume penjualan, harga maupun laba pada masa lalu.

2. Pasar efisien bentuk setengah kuat. Pasar dapat diklasifikasikan sebagai pasar bentuk setengah kuat apabila semua informasi publik yang ada tercermin dalam harga pasar. Informasi tersebut dapat berupa harga dari masa lalu, prediksi laba, data fundamental perusahaan maupun praktek akuntansi.

3. Pasar efisien bentuk kuat. Pasar dapat diklasifikasikan sebagai pasar bentuk kuat apabila harga saham sepenuhnya mencerminkan seluruh informasi yang diterima baik dari data historis, informasi publik maupun informasi yang sifatnya privat.

Dalam penelitianya, Bertuah (2014) menyatakan bahwa Bursa Efek Indonesia merupakan pasar dengan efisiensi bentuk setengah kuat. Pasar bentuk setengah kuat dapat dilihat dengan munculnya reaksi pasar saat menerima informasi baru yang saat ini sedang beredar.

\section{Studi Peristiwa}

Studi peristiwa merupakan sebuah studi yang menyelidiki respons pasar terhadap kandungan informasi dari suatu pengumuman atau publikasi peristiwa tertentu (Tandeilin, 2010). Menurut Hartono (2012) Studi peristiwa merupakan studi yang mempelajari reaksi pasar terhadap suatu peristiwa yang informasinya dipublikasikan 
sebagai suatu pengumuman. Studi peristiwa dapat digunakan untuk menguji kandungan informasi dari suatu peristiwa ataupun pengumumaan tertentu. Artinya jika suatu peristiwa ataupun pengumuman mengandung suatu informasi, maka diharapkan pasar akan bereaksi pada waktu pengumuman tersebut apabila diterima oleh pasar.

Reaksi tersebut dapat dilihat lewat adanya perubahan harga dari sekuritas bersangkutan dengan menggunakan return sebagai nilai perubahan harga atau abnormal return. Apabila suatu peristiwa ataupun pengumuman mempunyai kandungan informasi maka akan memberikan abnormal return kepada pasar. Abnormal return hanya akan terjadi pada satu atau dua titik waktu seputar pengumuman peristiwa. Apabila terjadi pada hampir semua spot maka mengindikasikan bahwa pasar tidak efisien karena pelaku pasar bereaksi terlalu cepat atau terlalu lambat terhadap suatu informasi. Sebaliknya apabila tidak mengandung informasi maka tidak memberikan abnormal return kepada pasar.

\section{Reaksi Pasar}

Reaksi pasar dapat dilihat apabila terdapat perubahan harga dari saham. Reaksi tersebut dapat diukur dengan melihat ada atau tidaknya abnormal return. Abnormal Return muncul apabila ada kandungan informasi dalam suatu peristiwa ataupun pengumuman. Bila suatu pengumuman mengandung informasi, maka pasar akan menerima abnormal retun dan sebaliknya jika suatu pengumuman tidak mengandung informasi maka pasar tidak akan menerima abnormal return (Hartono, 2012). Abnormal Return adalah selisih antara actual return dengan expected return. Hartono (2012) menyatakan bahwa abnormal return merupakan kelebihan dari return yang sesungguhnya terhadap return normal. Return normal adalah return ekspetasi atau return yang diharapkan oleh investor. Abnormal Return dibagi menjadi empat kategori (Samsul, 2006), yakni:

1. Abnormal Return (AR). Abnormal return merupakan selisih dari actual return dan expected return yang dihitung secara harian. Dengan demikian dapat diketahui abnormal return tertinggi dan terendah serta reaksi yang paling kuat pada hari-hari di event window.

2. Average Abnormal Return (AAR). Average abnormal return merupakan rata-rata dari semua jenis saham secara harian. Dengan menghitung average abnormal return maka 
dapat dilihat reaksi yang paling kuat dari seluruh jenis saham pada hari-hari di event window.

3. Cumulative Abnormal Return (CAR). Cumulative abnormal return merupakan akumulasi dari abnormal return harian pada semua jenis saham. Cumulative abnormal return dapat digunakan untuk membandingkan setiap jenis saham yang berpengaruh pada sebelum dan sesudah peristiwa.

4. Cumulative Average Abnormal Return (CAAR). Cumulative average abnormal return adalah akumulasi dari average abnormal return. Cumulative average abnormal return digunakan untuk mengetahui kecenderungan dampak suatu peristiwa. Kecenderungan dampak tersebut dapat dilihat dengan membandingkan cumulative average abnormal return sebelum peristiwa dan cumulative average abnormal return sesudah peristiwa.

Menurut Tandeilin (2010) terdapat tiga model yang secara luas digunakan untuk menentukan metode penyesuaian dalam menghitung abnormal return dalam penelitian event study. Pertama adalah model statistika yakni mean adjusted model (model rata-rata) dan market model (model pasar), kedua adalah market adjusted model (model disesuaikan pasar) dan terakhir adalah model-model ekonomika seperti Capital Asset Pricing Model (CAPM) dan Arbitrage Pricing Theory (APT). Periode estimasi diperlukan apabila perhitungan abnormal return menggunakan model statistik dan model ekonomika. Periode estimasi tidak diperlukan bila perhitungan abnormal return dihitung dengan menggunakan market adjusted model (model disesuaikan dengan pasar).

\section{Linimasa Peristiwa Revisi Renewable Energy Directive}

Peristiwa ini dimulai saat Komisi Eropa mengajukan proposal legistatif untuk merubah isi peraturan RED pada Parlemen Eropa tanggal 30 November 2016 yang isinya yakni pengusulan agar negara-negara di Uni Eropa mengurangi penggunaan biofuel berbasis tanaman pangan tahap demi tahap hingga 3,8 persen hingga tahun 2030. Peristiwa selanjutnya yakni pembacaan pertama 'single reading', Parlemen Eropa sepakat untuk mengadopsi proposal tersebut per 1 Maret 2017. Selanjutnya pada diskusi yang dilakukan oleh Dewan pada 6 Desember 2017, Komite Industri, Penelitian dan Energi Parlemen Eropa mengeluarkan rekomendasi yang lebih memberatkan indutri crude palm oil yakni dinihilkanya penggunaan crude palm oil sebagai produksi biofuel mulai tahun 2021. 
Pada 17 Januari 2018 dilakukan pemungutan suara untuk pengajuan proposal tersebut di Parlemen Eropa. Hasilnya proposal tersebut disetujui oleh 492 orang, ditolak 88 orang, sementara sisanya 107 orang menyatakan abstain. Berdasarkan keputusan tersebut, Parlemen Eropa memutuskan untuk mengadopsi proposal tersebut pada RED II. Artinya, Parlemen Eropa menyetujui bahwa pada tahun 2021 kontribusi biofuel yang dihasilkan oleh tanaman pangan yakni minyak sawit menjadi nihil atau 0 persen dalam perhitungan komsumsi energi bruto dari sumber energi terbarukan di semua negaranegara anggota Uni Eropa.

Indonesia segera membentuk tim untuk melobi pelarangan tersebut. Hasilnya dalam pertemuan trilogi antara Parlemen, Dewan dan Komisi Eropa memberikan kompromi terkait impor crude palm oil dari Indonesia. Kesepakatan ini menghasilkan amandemen pada peraturan RED II pada 14 Juni 2018. Dalam pertemuan tersebut diputuskan bahwa: (1) Uni Eropa akan mempertahankan volume impor serupa 2019, artinya konsumsi crude palm oil di Uni Eropa akan dikunci pada volume tertentu sepanjang tahun 2020 hingga 2023 sehingga biofuel akan dikaji dengan perlakuan yang sama tanpa melihat sumbernya; (2) Pada tahun 2024 kalkulasi untuk komoditas yang berisiko Indirect Land Use Change yakni minyak sawit akan diturunkan secara tahap demi tahap 'phase-out' sampai $0 \%$ pada tahun 2030. Artinya penggunaan minyak sawit akan dikurangi mencapai nihil pada 2030 sesuai dengan aturan revisi RED II yang berlaku.

\section{Kerangka Konseptual}

H1: Average Abnormal Return H-5 30 November 2016

H2: Average Abnormal Return H-5 17 Januari 2018

H3: Average Abnormal Return H-5 14 Juni 2018
H1: Average Abnormal Return H+5 30 November 2016

$\mathrm{H} 2$ : Average Abnormal Return H+5 17 Januari 2018

H3: Average Abnormal Return H+5 14 Juni 2018 


\section{Hipotesis}

H1: Terdapat perbedaan abnormal return yang signifikan sebelum atau sesudah peristiwa pengajuan proposal revisi RED terhadap harga saham perusahaan penghasil bahan baku sektor pertanian sub sektor perkebunan terdaftar Bursa Efek Indonesia.

H2: Terdapat perbedaan abnormal return yang signifikan sebelum atau sesudah peristiwa pemungutan suara terhadap harga saham perusahaan penghasil bahan baku sektor pertanian sub sektor perkebunan terdaftar Bursa Efek Indonesia.

H3: Terdapat perbedaan abnormal return yang signifikan sebelum atau sesudah peristiwa pertemuan trilogi terhadap harga saham perusahaan penghasil bahan baku sektor pertanian sub sektor perkebunan terdaftar Bursa Efek Indonesia.

\section{METODOLOGI PENELITIAN}

\section{Pendekatan Penelitian}

Penelitian ini menggunakan pendekatan kuantitatif dengan bentuk penelitian deskriptif komparatif. Komparatif adalah penelitian yang membandingkan keberadaan satu variabel atau lebih pada dua atau lebih sampel yang berbeda atau pada waktu yang berbeda (Sugiyono, 2015).

\section{Populasi dan Sampel}

Populasi penelitian ini adalah seluruh perusahaan penghasil bahan baku sektor pertanian sub sektor perkebunan yang terdaftar di Bursa Efek Indonesia pada 23 November 2016-7 Desember 2016, 10-24 Januari 2018 dan 4-26 Juni 2018. Berdasarkan populasi tersebut maka penelitian ini dilakukan pada 48 perusahaan. Sampel dalam penelitian ini dipilih menggunakan teknik purpossive sampling atau berdasarkan kriteria tertentu (Sugiyono, 2015). Penelitian ini dilakukan dengan 10 hari ( $\mathrm{H}-5$ dan $\mathrm{H}+5)$ selama tiga kali observasi pada peristiwa di pengajuan proposal revisi RED, pemungutan suara dan pertemuan trilogi sehingga akumulasi jumlah perusahaan yang akan diteliti sesuai kriteria yaitu sebanyak 47 perusahaan pada sektor perkebunan perusahaan penghasil energi di Bursa Efek Indonesia.

\section{Definisi Operasional Variabel}

Berikut ini adalah dijelaskan mengenai definisi operasional variabel yang akan digunakan dalam penelitian ini: 
Tabel 2. Definisi Operasional dan Pengukuran Variabel

\begin{tabular}{|c|l|l|c|}
\hline No & Variabel & \multicolumn{1}{|c|}{ Skala } & Pengukuran \\
\hline 1 & $\begin{array}{l}\text { Abnormal } \\
\text { Return }\end{array}$ & $\begin{array}{l}\text { Hartono (2012;579) mendefinisikan abnormal } \\
\text { return 'return tak normal' sebagai kelebihan dari } \\
\text { return yang sesungguhnya terhadap return } \\
\text { ekspetasi. }\end{array}$ & $A R_{i t}=R_{i t}-e\left[R_{i t}\right]$ \\
\hline 2 & $\begin{array}{l}\text { Actual } \\
\text { Return }\end{array}$ & $\begin{array}{l}\text { Actual Return merupakan return yang terjadi } \\
\text { pada waktu ke-t yang merupakan selisih harga } \\
\text { sekarang relatif terhadap harga sebelumnya. }\end{array}$ & $R_{i t}=\frac{P_{i t}-P_{i t-1}}{P_{i t-1}}$ \\
\hline 3 & $\begin{array}{l}\text { Expected } \\
\text { Return }\end{array}$ & $\begin{array}{l}\text { Expected return akan dihitung dengan market } \\
\text { adjusted model. Dalam model ini peneliti } \\
\text { menggunakan Indeks Harga Saham Gabungan } \\
\text { sebagai indikator kegiatan pasar modal. }\end{array}$ & $R_{m t}=\frac{I H S G_{1}-I H S G_{t-1}}{I H S G_{t-1}}$ \\
\hline
\end{tabular}

Sumber: Penulis (2019)

\section{Sumber Data dan Jenis Data}

Jenis data yang digunakan dalam penelitian ini adalah data sekunder. Sumber data dari data historis seluruh perusahaan penghasil bahan baku sektor pertanian sub sektor perkebunan yang terdaftar di Bursa Efek Indonesia periode 23 November 2016 hingga 26 Juni 2018 yang diunduh dari investing.com.

\section{Teknik Pengumpulan Data}

Dalam penelitian ini pengumpulan data yaitu dokumentasi. Teknik ini dilakukan dengan membaca dan mencatat data historis dari perusahaan-perusahaan penghasil bahan baku sektor pertanian sub sektor perkebunan yang terdaftar di Bursa Efek Indonesia periode 23 November 2016 hingga 26 Juni 2018 yang diunduh dari investing.com, serta jurnal-jurnal yang terkait dengan penelitian dan berita-berita daring terkait dengan peristiwa revisi Renewable Energy Directive.

\section{Teknik Analisis Data}

Metode analisis yang digunakan dalam menganalisis data pada penelitian ini adalah statistik deskriptif, uji normalitas dan pengujian hipotesis. Peneliti menggunakan analisis rasio keuangan yang didahului dengan analisis statistik deskriptif yang dapat dilihat dari nilai rata-rata 'mean', standar deviasi, serta nilai maksimum dan minimum dari abnormal return pada lima hari sebelum dan sesudah peristiwa proposal revisi RED, pemungutan suara dan pertemuan trilogi. 


\section{HASIL DAN PEMBAHASAN}

\section{Hasil Uji Normalitas}

Metode uji normalitas data yang digunakan dalam penelitian ini adalah Shapiro Wilk test. Tujuan dilakukanya uji normalitas adalah untuk mengetahui apakah data yang digunakan terdistribusi normal atau tidak sehingga dapat menentukan alat analisis yang tepat pada saat pengujian hipotesis.

Tabel 3. Uji Normalitas Average Abnormal Return Peristiwa Pengajuan Proposal Revisi Renewable Energy Directive

\begin{tabular}{|c|c|c|}
\hline & AAR Sebelum Peristiwa & AAR Sesudah Peristiwa \\
\hline Statistic & 0,970 & 0,589 \\
\hline $\mathrm{df}$ & 15 & 15 \\
\hline Sig. & 0,865 & 0,000 \\
\hline
\end{tabular}

Sumber: Penulis (2019)

Berdasarkan hasil pengujian normalitas average abnormal return pada kedua periode pada sebelum peristiwa pengajuan proposal revisi RED terdistribusi normal karena nilai taraf signifikansi adalah 0,589 atau lebih besar dari 0,05 (0,589 20,05). Sedangkan nilai taraf signifikansi pada sesudah peristiwa pengajuan proposal pengajuan proposal revisi RED adalah 0,000 atau lebih kecil dari 0,05 $(0,000 \leq 0,05)$ artinya terdistribusi tidak normal. Oleh karena itu dapat disimpulkan bahwa data pada peristiwa pengajuan proposal revisi RED memiliki inkonsistensi taraf signifikansi pada kedua periode. Sehingga selanjutnya uji hipotesis yang dilakukan adalah dengan menggunakan uji parametric paired sample t-test dan nonparametric wilcoxon signed rank test.

Tabel 4. Uji Normalitas Average Abnormal Return Peristiwa Pemungutan Suara

\begin{tabular}{|c|c|c|}
\hline & AAR Sebelum Peristiwa & AAR Sesudah Peristiwa \\
\hline Statistic & 0,868 & 0,888 \\
\hline $\mathrm{df}$ & 16 & 16 \\
\hline Sig. & 0,025 & 0,053 \\
\hline
\end{tabular}

Sumber: Penulis (2019)

Hasil pengujian normalitas average abnormal return pada saat peristiwa menunjukan bahwa data average abnormal return pada sebelum peristiwa pemungutan suara terdistribusi tidak normal karena nilai taraf signifikansi adalah 0,025 atau lebih kecil dari 0,05 $(0,025 \leq 0,05)$. Sedangkan nilai taraf signifikansi pada sesudah peristiwa pemungutan suara adalah 0,000 atau lebih besar dari $0,05(0,053 \geq 0,05)$ artinya terdistribusi normal. Oleh karena itu dapat disimpulkan bahwa data pada peristiwa pemungutan suara memiliki inkonsistensi taraf signifikansi pada kedua periode. 
selanjutnya uji hipotesis yang dilakukan adalah dengan menggunakan uji parametric paired sample t-test dan nonparametric wilcoxon signed rank test.

Tabel 5. Uji Normalitas Average Abnormal Return Peristiwa Pertemuan Trilogi

\begin{tabular}{|c|c|c|}
\hline & AAR Sebelum Peristiwa & AAR Sesudah Peristiwa \\
\hline Statistic & 0,970 & 0,589 \\
\hline $\mathrm{df}$ & 15 & 15 \\
\hline Sig. & 0,865 & 0,000 \\
\hline
\end{tabular}

Sumber: Penulis (2019)

Sedangkan hasil pengujian normalitas average abnormal return pada peristiwa trilogi menunjukan bahwa kedua data terdistribusi normal karena keduanya memiliki taraf signifikansi lebih besar dari 0,05. Nilai taraf signifikansi pada saat sebelum peristiwa adalah 0,167 $(0,167 \geq 0,05)$ dan nilai taraf signifikansi sesudah peristiwa adalah $0,489(0,489 \geq 0,05)$. Sehingga selanjutnya uji hipotesis yang dilakukan adalah dengan menggunakan paired sample t-test.

\section{Hasil Uji Hipotesis}

Pengujian hipotesis dilakukan dengan dua alternatif uji beda. Apabila data terdistribusi normal maka dilakukan uji parametric dengan paired sample $t$-test, namun jika data tidak terdistribusi normal maka dilakukan uji nonparametric dengan wilcoxon signed rank test.

Tabel 6. Wilcoxon Signed Rank Test Average Abnormal Return Peristiwa Pengajuan Proposal

\begin{tabular}{|c|c|}
\hline & AAR Sesudah Peristiwa - AAR Sebelum Peristiwa \\
\hline Z & $-1.818^{\mathrm{b}}$ \\
\hline Sig. (2-Tailed) & 0,069 \\
\hline
\end{tabular}

Sumber: Penulis (2020)

Tabel 7. Paired Sample T-test Average Average Abnormal Return Peristiwa Pengajuan Proposal

\begin{tabular}{|c|c|c|c|}
\hline \multirow{4}{*}{$\begin{array}{c}\text { Paired } \\
\text { Differences }\end{array}$} & \multicolumn{2}{|l|}{ Mean } & 0,006150 \\
\hline & \multicolumn{2}{|l|}{ Std. Deviation } & 0,017132 \\
\hline & \multicolumn{2}{|l|}{ Std. Error Mean } & 0,004424 \\
\hline & $\begin{array}{l}\text { 95\% Confidence Interval of the } \\
\text { Difference }\end{array}$ & $\begin{array}{l}\text { Lower } \\
\text { Upper }\end{array}$ & -0.003338 \\
\hline \multicolumn{3}{|c|}{$\mathrm{t}$} & 0,1390 \\
\hline \multicolumn{3}{|c|}{$\mathrm{df}$} & 14 \\
\hline \multicolumn{3}{|c|}{ Sig (2-tailed) } & 0,186 \\
\hline
\end{tabular}

Sumber: Penulis (2020)

Hasil pengujian parametric paired sample t-test pada average abnormal return pada peristiwa pengajuan revisi proposal RED menunjukan nilai sig. (2-tailed) sebesar 0,186 $(0,186>0,05)$. Artinya hasil uji dari uji parametric menyatakan bahwa tidak ada perbedaan secara signifikan yang ada di average abnormal return saat sebelum dan sesudah peristiwa pengajuan revisi proposal RED. Sedangkan hasil pengujian wilcoxon 
signed rank test pada average abnormal return pada peristiwa pengajuan proposal revisi RED menunjukan nilai sig. (2-tailed) sebesar 0,069 (0,069>0,05). Artinya hasil uji nonparametric menyatakan bahwa tidak ada perbedaan secara signifikan yang ada di average abnormal return saat sebelum dan sesudah peristiwa pengajuan proposal revisi RED. Oleh karena itu hasil penelitian menyatakan bahwa $\mathrm{H}_{0}$ diterima dan $\mathrm{H}_{1}$ ditolak.

Tabel 8. Wilcoxon Signed Rank Test Average Abnormal Return Peristiwa Pemungutan Suara

\begin{tabular}{|c|c|}
\hline & AAR Sesudah Peristiwa - AAR Sebelum Peristiwa \\
\hline$Z$ & $-.155^{\mathrm{b}}$ \\
\hline Sig. (2-Tailed) & 0,0877 \\
\hline
\end{tabular}

Sumber: Penulis (2020)

Tabel 9. Paired Sample T-test Average Average Abnormal Return Peristiwa Pemungutan Suara

\begin{tabular}{|c|c|c|c|}
\hline \multirow{4}{*}{$\begin{array}{c}\text { Paired } \\
\text { Differences }\end{array}$} & \multicolumn{2}{|l|}{ Mean } & 0,001025 \\
\hline & \multicolumn{2}{|l|}{ Std. Deviation } & 0,017725 \\
\hline & \multicolumn{2}{|l|}{ Std. Error Mean } & 0,004431 \\
\hline & $\begin{array}{c}\text { 95\% Confidence Interval of the } \\
\text { Difference }\end{array}$ & $\begin{array}{l}\text { Lower } \\
\text { Upper }\end{array}$ & $\begin{array}{r}-0.008420 \\
0,010470\end{array}$ \\
\hline \multicolumn{3}{|c|}{$t$} & 0,231 \\
\hline \multicolumn{3}{|c|}{$\mathrm{df}$} & 15 \\
\hline \multicolumn{3}{|c|}{ Sig (2-tailed) } & 0,820 \\
\hline
\end{tabular}

Sumber: Penulis (2020)

Hasil pengujian parametric paired sample t-test pada average abnormal return pada peristiwa pengajuan revisi proposal RED menunjukan nilai sig. (2-tailed) sebesar 0,820 $(0,820>0,05)$. Artinya hasil uji ini dari uji parametric menyatakan bahwa tidak ada perbedaan secara signifikan yang ada di average abnormal return saat sebelum dan sesudah peristiwa pemungutan suara. Sedangkan hasil pengujian wilcoxon signed rank test pada average abnormal return pada peristiwa pemungutan suara menunjukan nilai sig. (2-tailed) sebesar 0,0877 $(0,877>0,05)$. Artinya hasil uji nonparametric menyatakan bahwa tidak ada perbedaan secara signifikan yang ada di average abnormal return saat sebelum dan sesudah peristiwa pengajuan pemungutan suara, sehingga hasil penelitian menyatakan bahwa $\mathrm{H}_{0}$ diterima dan $\mathrm{H}_{1}$ ditolak.

Tabel 10. Paired Sample T-test Average Average Abnormal Return Peristiwa Pertemuan Trilogi

\begin{tabular}{|c|c|c|c|}
\hline \multirow{4}{*}{$\begin{array}{c}\text { Paired } \\
\text { Differences }\end{array}$} & \multicolumn{2}{|l|}{ Mean } & 0,004557 \\
\hline & \multicolumn{2}{|c|}{ Std. Deviation } & 0,012049 \\
\hline & \multicolumn{2}{|c|}{ Std. Error Mean } & 0,003012 \\
\hline & $\begin{array}{l}\text { 95\% Confidence Interval of } \\
\text { the Difference }\end{array}$ & $\begin{array}{l}\text { Lower } \\
\text { Upper }\end{array}$ & $\begin{array}{r}-0.00186 \\
0,0018637\end{array}$ \\
\hline \multicolumn{3}{|c|}{$\mathrm{t}$} & 1,513 \\
\hline \multicolumn{3}{|c|}{$\mathrm{df}$} & 15 \\
\hline \multicolumn{3}{|c|}{ Sig (2-tailed) } & 0,151 \\
\hline
\end{tabular}

Sumber: Penulis (2020) 
Hasil pengujian paired sample t-test pada average abnormal return pada peristiwa pertemuan trilogi menunjukan nilai sig. (2-tailed) sebesar 0,000 $(0,531>0,05)$. Artinya bahwa ada tidak perbedaan secara signifikan pada average abnormal return saat sebelum dan sesudah peristiwa pertemuan trilogi. Oleh karena itu hasil penelitian menyatakan bahwa $\mathrm{H}_{1}$ ditolak dan $\mathrm{H}_{0}$ diterima.

\section{Pembahasan}

Peristiwa diajukan proposal revisi Renewable Energy Directive berlangsung pada tanggal 30 November 2016. Penulis melakukan pengamatan untuk mendokumentasikan beritaberita terkait pada periode pengamatan dengan mencari berita elektronik menggunakan mesin pencari Google dengan kata kunci: (1) Delegated Act Uni Eropa; (2) Revisi Renewable Energy Directive dan (3) Uni eropa kelapa sawit. Pengamatan tersebut menghasilkan kesimpulan bahwa tidak ada satu beritapun yang membahas peristiwa ini. Penulis hanya mendapatkan satu berita yang berkaitan dengan Eropa dan kelapa sawit namun tidak berhubungan dengan peristiwa ini pada laman Kompas yang isinya mengenai tuntutan Menteri Bantuan Pembangunan Jerman Gerd Müller terhadap industri sawit Indonesia dan laporan amnesty international berjudul "The Great Palm Oil Scandal: Labour Abuses Behind Big Brand Names" yang membahas mengenai skandal hak asasi manusia dalam industri sawit. Oleh karena itu bisa disimpulkan bahwa peristiwa ini tidak mengandung informasi apapun karena tidak diberitakan oleh media nasional sehingga tidak terjadi reaksi pasar.

\section{Peristiwa Pemungutan Suara}

Berita yang berkaitan dengan isu revisi Renewable Energy Directive mulai diberitakan pertengahan tahun 2017. Begitupula berita-berita yang muncul pada periode pengaatan Peristiwa Pemungutan Suara. Hasil pencarian menggunakan mesin pencarian Google menunjukan ada 10 halaman hasil pencarian untuk kata kunci "Kelapa sawit Eropa". Artinya isu mengenai revisi Renewable Energy Directive sebenarnya tidak terlalu diperhatikan oleh masyarakat meski sudah banyak diberitakan, penulis menduga hal tersebut diakibatkan dari literasi lingkungan masyarakat Indonesia masuk dalam environmental illiteracy yakni hanya sedikit mengetahui isu lingkungan. Padahal isu deforestasi merupakan isu yang diangkat oleh Komisi Eropa untuk melarang crude palm oil dari Indonesia. Pengamatan average actual return pada periode peristiwa juga 
menunjukan bahwa average actual return bergerak fluktuatif (Gambar 4.1). Artinya perusahaan masih dapat legitimate dengan masyarakat Indonesia yang environmental illiteracy. Dapat pula disimpulkan bahwa investor lebih mempercayakan kinerja perusahaan dan menganggap bahwa isu revisi Renewable Energy Directive dalam peristiwa ini tidak akan terlalu berdampak terhadap saham.

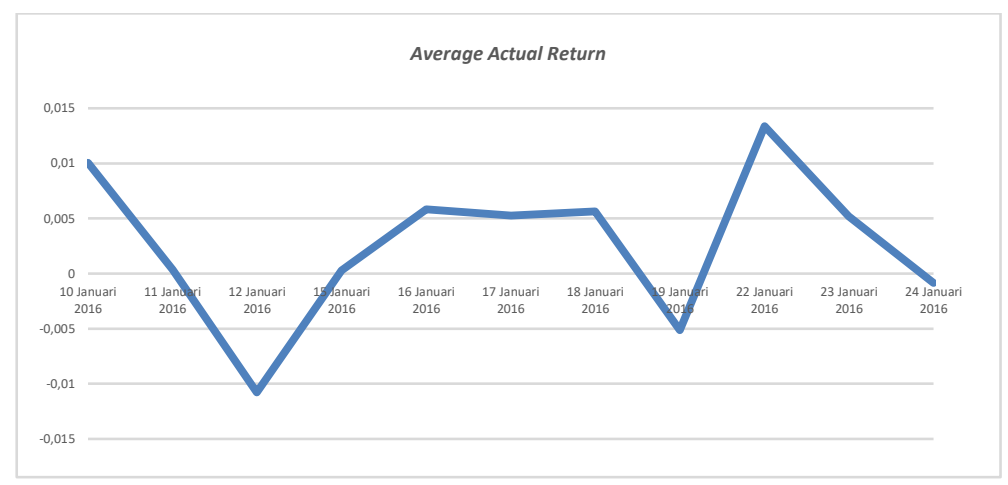

Grafik 2. Tren Average Actual Return Periode Peristiwa Pemungutan Suara

Sumber: Diolah Pribadi (2019)

Pada 17-23 Januari 2018 harga tandan buah segar (TBS) tawit mengalami kenaikan. Dikutip dari GAPKI (2018) pada periode tersebut harga TBS sawit naik sebesar Rp55,52/ kg dari periode sebelumnya. Pengamatan terhadap average actual return saham juga menunjukan bahwa average actual return tertinggi selama periode pengamatan penelitian terjadi pada 22 Januari 2018. Artinya meski didesak oleh isu negatif berkaitan dengan sawit Indonesia dan peristiwa pemungutan suara namun industri kelapa sawit masih dapat memberikan kinerja yang baik.

\section{Peristiwa Pertemuan Trilogi}

Indonesia yang tidak terima dengan keputusan pada pemungutan suara akhirnya melobi Eropa sehingga terjadilah pertemuan trilogi. Hasil dari pertemuan yang dilakukan oleh Parlemen Uni Eropa, Komisi Uni Eropa dan Dewan Eropa pada tanggal 14 Juni 2018 adalah diundurnya implementasi amandemen Renewable Energy Directive tahap demi tahap hingga diterapkan secara penuh pada tahun 2030. Artinya, ini adalah hal positif bagi Indonesia karena masih memiliki kesempatan untuk menjual produk sawitnya ke Eropa hingga tahun 2030. Peristiwa pertemuan trilogi berlangsung pada tanggal 14 Juni 2018 dimana Bursa Efek Indonesia sedang tidak aktif karena adanya libur hari raya nasional. Bursa Efek Indonesia dibuka kembali pada tanggal 20 Juni 2018 atau 6 hari setelah peristiwa. Artinya informasi mengenai peristiwa pertemuan trilogi yang 
diterima masyarakat sudah kadaluarsa. Bursa Efek Indonesia adalah pasar setengah efisien, sehingga pasar bereaksi cepat ketika suatu peristiwa mengandung informasi.

\section{KESIMPULAN}

Penelitian ini bertujuan untuk untuk mengetahuui adanya perbedaan abnormal return pada peristiwa pengajuan proposal revisi Renewable Energy Directive, pemungutan suara dan pertemuan trilogi. Berdasarkan analisi data dan pembahasan dari hasil penelitian maka dapat diambil kesimpulan:

1. Berdasarkan hasil uji hipotesis menggunakan wilcoxon signed rank test dan paired sample t-test dapat terlihat bahwa nilai signifikansi lebih kecil dari 0,05. Artinya tidak ada perbedaan average abnormal return pada peristiwa pengajuan proposal revisi Renewable Energy Directive.

2. Berdasarkan hasil uji hipotesis menggunakan wilcoxon signed rank test dan paired sample t-test dapat terlihat bahwa nilai signifikansi lebih kecil dari 0,05. Hal ini menunjukan bahwa tidak terdapat perbedaan average abnormal return pada peristiwa pemungutan suara.

3. Berdasarkan hasil uji hipotesis menggunakan paired sample t-test dapat terlihat bahwa nilai signifikansi lebih kecil dari 0,05. Hal ini menandakan bahwa tidak terdapat perbedaan average abnormal return pada peristiwa pertemuan trilogi.

\section{REKOMENDASI}

Untuk penelitian selanjutnya agar menambahkan variabel trading volume activity, serta menggunakan model mean adjusted. Peneliti selanjutnya juga dapat menambahkan uji one sample t-test untuk mengetahui arah reaksi pasar peristiwa.

\section{DAFTAR PUSTAKA}

Arde, Hatta Diman dan Ketut Wijaya Kesuma. 2017. Studi Peristiwa Tragedi Sarinah Terhadap Pasar Modal Indonesia. E-Jurnal Manajemen Unud, Vol. 6, No. 6. ISSN: 2302-8912. Hlm: 3080 - 3110.

Bertuah, Eka. 2014. Pendeteksian Market Information Yang Mempengaruhi Kinerja Bursa Efek Indonesia. Jurnal Ekonomi, Vol. 5, No. 2. Hlm. 61-68.

Bodie, Zvi, Alex Kane dan Alan J. Marcus. 2014. Investment. McGraw Hill Education. New York. 
Hartono, Jogiyanto. 2012. Teori Portofolio dan Analisis Investasi. BPFE. Yogyakarta.

Purba, Fransisko \& Siti Ragil Handayani. 2017. Analisis Perbedaan Reaksi Pasar Modal Indonesia Sebelum dan Sesudah Peristiwa Non Ekonomi (Studi pada Peristiwa Politik Pilkada DKI Jakarta 2017 Putaran Kedua). Jurnal Administrasi Bisnis (JAB), Vol. 51, No. 1. Hlm: 115 - 123.

Samsul, Mohammad. 2006. Pasar Modal \& Manajemen Portofolio. Erlangga. Jakarta.

Sidik, M. Muhayyin A. 2017. Reaksi Pasar Atas Peristiwa Pencemaran Lingkungan Pada Perusahaan Yang Terdaftar di Bursa Efek Indonesia. Universitas Lampung. Lampung.

Tandelilin, Eduardus. 2010. Portofolio dam Investasi: Teori dan Aplikasi. PT Kanisius: Yogyakarta.

Yulita, Ima Krisitina. 2017. Reaksi Pasar Modal terhadap Keputusan Investasi Raja Salman di Indonesia. Jurnal Penelitian, Vol. 21, No. 1. Hlm: 95 - 106. 